\title{
Insights into Mejerda basin hydrogeology, Tunisia
}

\author{
Rihab Guellala • Mohamed Ali Tagorti • \\ Mohamed Hédi Inoubli • Faouzi Amri
}

Received: 12 November 2011 / Accepted: 29 March 2012/Published online: 18 April 2012

(C) The Author(s) 2012. This article is published with open access at Springerlink.com

\begin{abstract}
The present study concentrates on the interpretation of Vertical Electrical Soundings (VES) and well logs to understand the geometry and the functioning of the Ghardimaou multilayered aquifer, a potential target for water supply in the Mejerda basin (Tunisia). The analysis of isobath and isopach maps established in this study, shows a tectonic influence on the reservoirs structure; the Villafranchian folding and the NE-SW, and E-W normal faulting in the recent Quaternary created an aquifer system compartmentalized by raised and tilted blocks. Geoelectrical cross sections reveal that this structure influences the thickness of permeable formations and the groundwater circulation. These results will be useful for rationalizing the future hydrogeological research that will be undertaken in the Mejerda basin.
\end{abstract}

Keywords Vertical electrical sounding - Well logging · Compartmentalized aquifer · Tunisia

R. Guellala ( $\square)$

Laboratoire de Géoressources, CERTE, Pôle Technologique de Borj Cédria, Université de Carthage, 8020 Soliman, Tunisia e-mail: gallalarabie@yahoo.fr

\section{A. Tagorti}

Institut Supérieur de Biotechnologie de Monastir,

Monastir, Tunisia

M. H. Inoubli

Département des Sciences de la Terre, FST,

Université Tunis El Manar, 1060 Tunis, Tunisia

F. Amri

Direction Générale des Ressources en Eaux, Tunis, Tunisia

\section{Introduction}

The determination of the aquifer geometry is a major step for the understanding of the hydrogeological systems (Zouhri 2001; Cudennec et al. 2007; Rapti-Caputo et al. 2009; Guellala et al. 2011a, b, c). The defined structures may control the relationship between the hydrogeological units and the groundwater flow.

In Tunisia, the Mejerda basin is one of the most important agricultural sectors (Fig. 1). It has strong need for irrigation water. During rainy periods, Oued Mejerda River and its tributaries are the main sources to irrigate the vegetation. However, the periodical occurrence of several years of drought renders necessary the exploitation of the underground water reserves to fulfil the water need.

The Ghardimaou area (Fig. 1) occupies the Western part of the Mejerda basin. Its surface is about $300 \mathrm{~km}^{2}$ and its population is estimated at 90,000 inhabitants.

The Ghardimaou area is characterized by moderate temperatures which oscillate between 8 and $17^{\circ} \mathrm{C}$ in winter and between 25 and $30{ }^{\circ} \mathrm{C}$ in summer. The annual rainfall is on average $400 \mathrm{~mm} /$ year and the evaporation is about $1,300 \mathrm{~mm} /$ year.

The Ghardimaou aquifer system appears as a potential resource able to provide interesting flows. However, former geological and hydrogeological studies in this region were not sufficient to propose zones and strategies for the exploitation of this resource. Tectonic and sedimentary phenomena and their impact on the aquifer functioning had not been elucidated. The aim of this study is, therefore, to determine the deposit structures to improve the understanding of the aquifer system.

The electrical resistivity method, usually applied in the aquifers' prospection (Keller and Frischknecht 1982; Meyer de Stadelhofen 1991; Majumdar et al. 2000; 


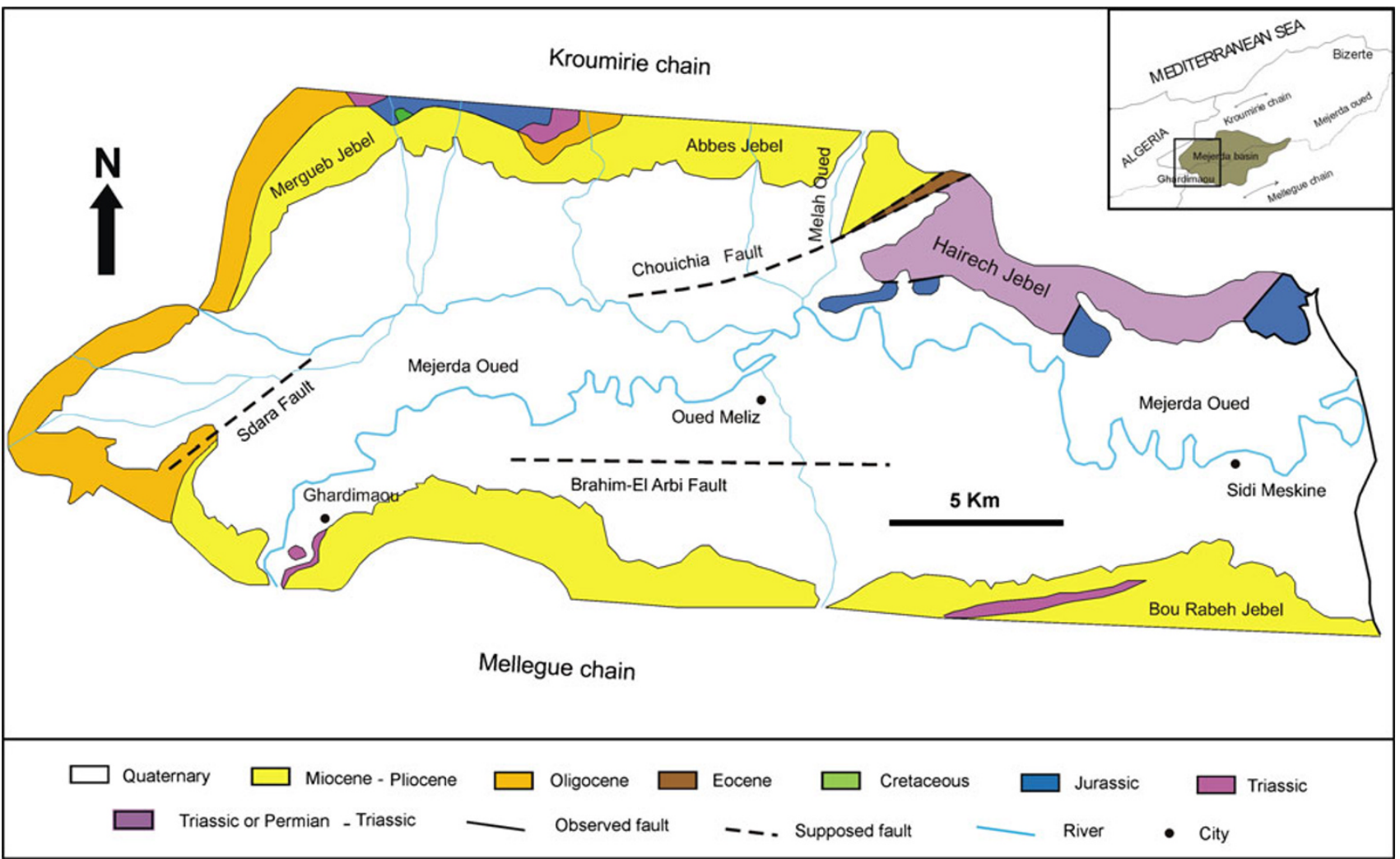

Fig. 1 Study area setting

Shaaban 2001; Koussoubé et al. 2003; Zouhri et al. 2004; Asfahani 2006; Gouasmia et al. 2006; Guellala et al. 2009a, b, 2010, 2011c; Tizro et al. 2010; Pertu et al. 2011) appears as an appropriate method able to guarantee a good knowledge of the Ghardimaou aquifer system.

\section{Geolgical setting}

The Ghardimaou plain corresponds to the western part of the Mejerda molassic basin. Its margins are represented by the Kroumirie Mountains with thrust nappes in the north (Rouvier 1977; Ould Begga et al. 2006; Riahi et al. 2010) and the Mellegue Mountains in the south (Fig. 1).

The Mejerda basin is filled with sedimentary rocks with ages ranging from Mio-Pliocene to Quaternary. The Quaternary sediments are made of clays, gravels and sands. The Miocene-Pliocene sediments consist of clays conglomerates, sandstones and marls (Gottis and Sainfeld 1955; Biely 1972).

In the Ghardimaou plain, the Quaternary deposits show a remarkable thickening from the borders to the centre and from the east to the west. Variable substratum underlies these deposits: The Hairech series dated Triassic (Bolze 1954; Rouvier 1977; Perthuisot 1978) or even PermianTriassic (Burollet 1973; Alouani and Tlig 1988; Alouani et al. 1991), the Jurassic and the Miocene-Pliocene (Fig. 2).

Chouichia fault, Sdara fault and Brahim El Arbi fault, which are the dominant tectonic features in the plain (Fig. 1) affect this substratum and controlled the Quaternary sedimentation (Gottis and Sainfeld 1955; Parsons Company 1967; Rouvier 1977; Ould Begga 2003; Guellala et al. 2008).

Seismological studies show the continuous activity of these faults (Hfaiedh et al. 1985; Ben Ayed 1986; Gueddiche et al. 1992; Dlala 1995; Krima 2001).

\section{Hydrogeological setting}

The Ghardimaou plain contains a multilayered aquifer system made up of Quaternary permeable deposits, which is recharged by the Oued Mejerda River and its tributaries.

Former hydrogeological studies (Parsons Company 1967; Andrieux and Talbot 1972; Guellala et al. 2005a, b) distinguished three major aquifers separated by clayey layers:

- Shallow aquifer: essentially constituted of sands, gravels and cobbles. This aquifer, which is found at about 10-20 $\mathrm{m}$ depth, over all the plain. Its thickness varies 


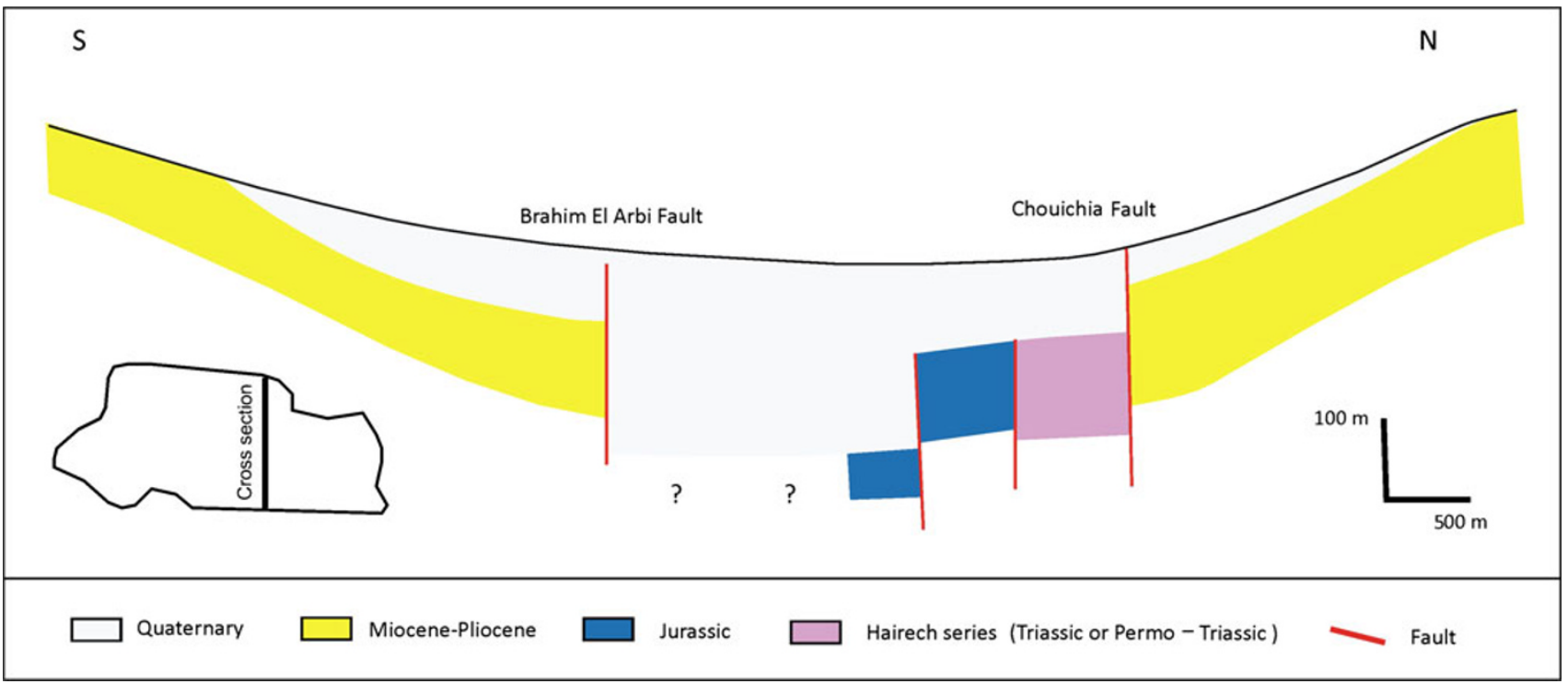

Fig. 2 Geological cross section

between 3 and $45 \mathrm{~m}$ showing the higher values in the western and central zones of the aquifer.

- Main aquifer: it is located at $55 \mathrm{~m}$ depth on average and is made up of gravels, sands, cobbles, clayey gravels and thin clayey beds. The thickness of this aquifer decreases toward the plain's borders. It reaches $100 \mathrm{~m}$ thick between Oued Mejerda and Oued Rarai rivers.

- Deep aquifer: this aquifer is composed of sands and gravels cemented by clays which makes them have a lower permeability. It is considered as a lenticular and discontinuous aquifer. It disappears toward the northern and the eastern parts of the plain. In the center part of the plain, its upper surface is between 210 and $280 \mathrm{~m}$ depth.

In addition to these, another aquifer was identified in the western part of the plain (Guellala et al. 2005a). It is found at about $150 \mathrm{~m}$ depth, between the main and the deep aquifer, and its thickness exceeds $50 \mathrm{~m}$.

The piezometric maps elaborated for the shallow and main aquifers (Guellala 2004) show that the water level decreases from the west to the east indicating a groundwater flow in this direction (Fig. 3). Data are insufficient to establish piezometric maps for the other aquifers.

\section{Data and methods}

The present study is based on Vertical Electrical Sounding (VES) associated to water boreholes (lithological columns and corresponding wells logs). These data were provided by the Tunisian "General Directorate of Water Resources" in Tunisia.
Vertical Electrical Sounding data acquisition was performed at 42 locations (Fig. 4). The Schlumberger configuration was used with a maximum electrode spacing of 2,000 m.

An electrical field is imposed on the inland area by a pair of electrodes (A and B) at varying spacing, expanding symmetrically from a central point, while measuring the surface expression of the resulting potential field with an additional pair of electrodes ( $\mathrm{M}$ and $\mathrm{N}$ ) at appropriate much smaller spacing. Apparent resistivity " $\rho_{\mathrm{a}}$ " is subsequently computed according to the following equation (Dobrin 1976):

$\rho_{\mathrm{a}}=\frac{2 \pi}{(1 / \mathrm{AM})-(1 / \mathrm{BM})-(1 / \mathrm{AN})+(1 / \mathrm{BN})} \times \frac{\Delta V}{I}$

Where, $I$ is the current introduced into the earth by A and $\mathrm{B}$ electrodes, $\Delta V$ is the potential difference between $\mathrm{M}$ and $\mathrm{N}$ electrodes and $\mathrm{AM}, \mathrm{BM}, \mathrm{AN}$ and $\mathrm{BN}$ are distances between the electrodes.

Apparent resistivity values obtained at each vertical electrical sounding are represented in the form of curves $\rho_{\mathrm{a}}=f(\mathrm{AB})$ with logarithmic coordinates.

The determination of initial thicknesses and resistivities is manually obtained by matching the VES field curves to the theoretical master curves and auxiliary point charts. These parameters are subsequently refined using an inverse technique implemented in WINSEV program (Jenny and Borreguerro 1993). The result is achieved when a good fit between the field data and the theoretically computed curve is obtained.

Interpretation problems, such as equivalence or suppression, show that the same electrical sounding curve 


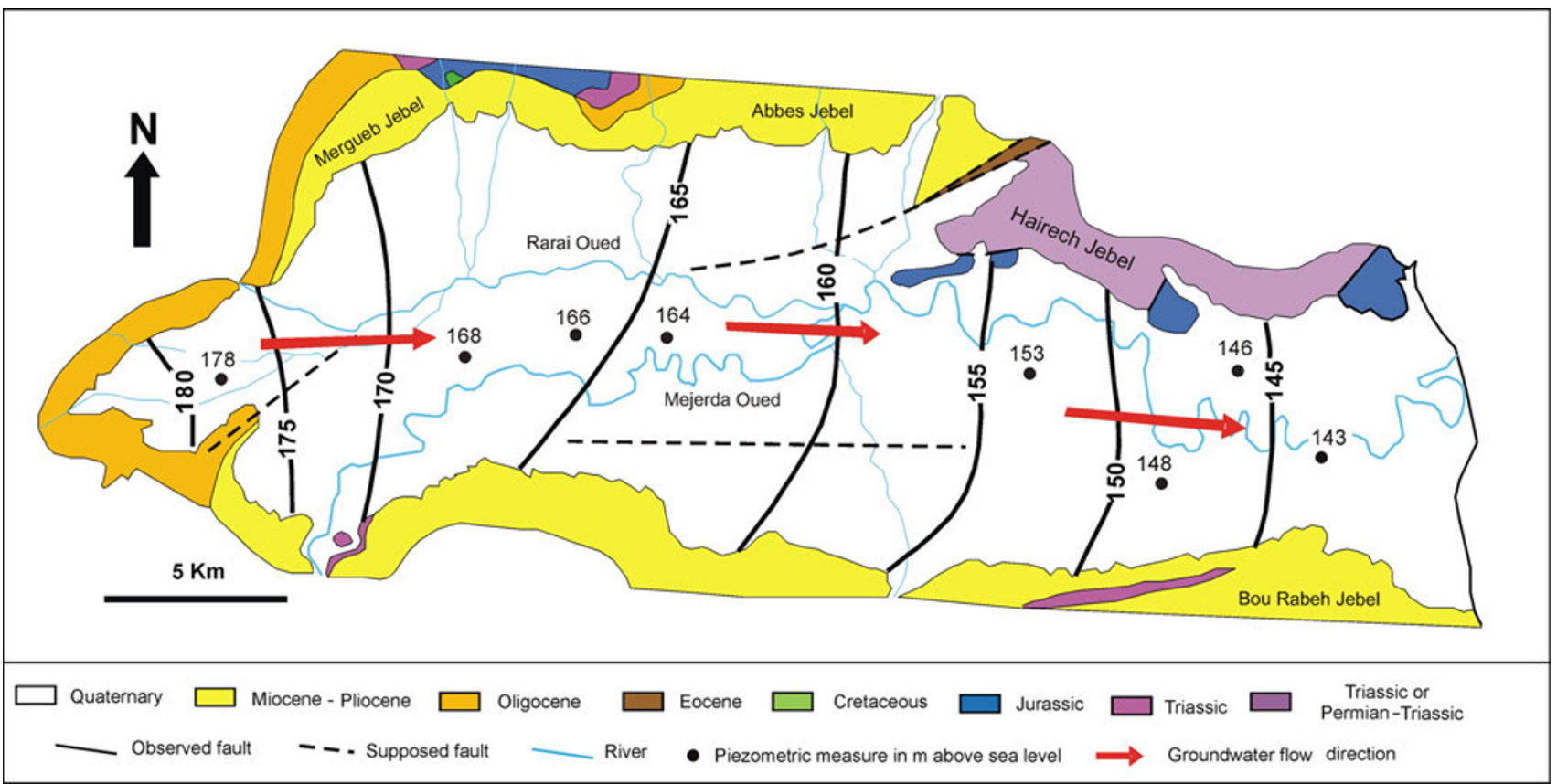

Fig. 3 Main aquifer piezometric map

Fig. 4 Location of water wells and electrical soundings

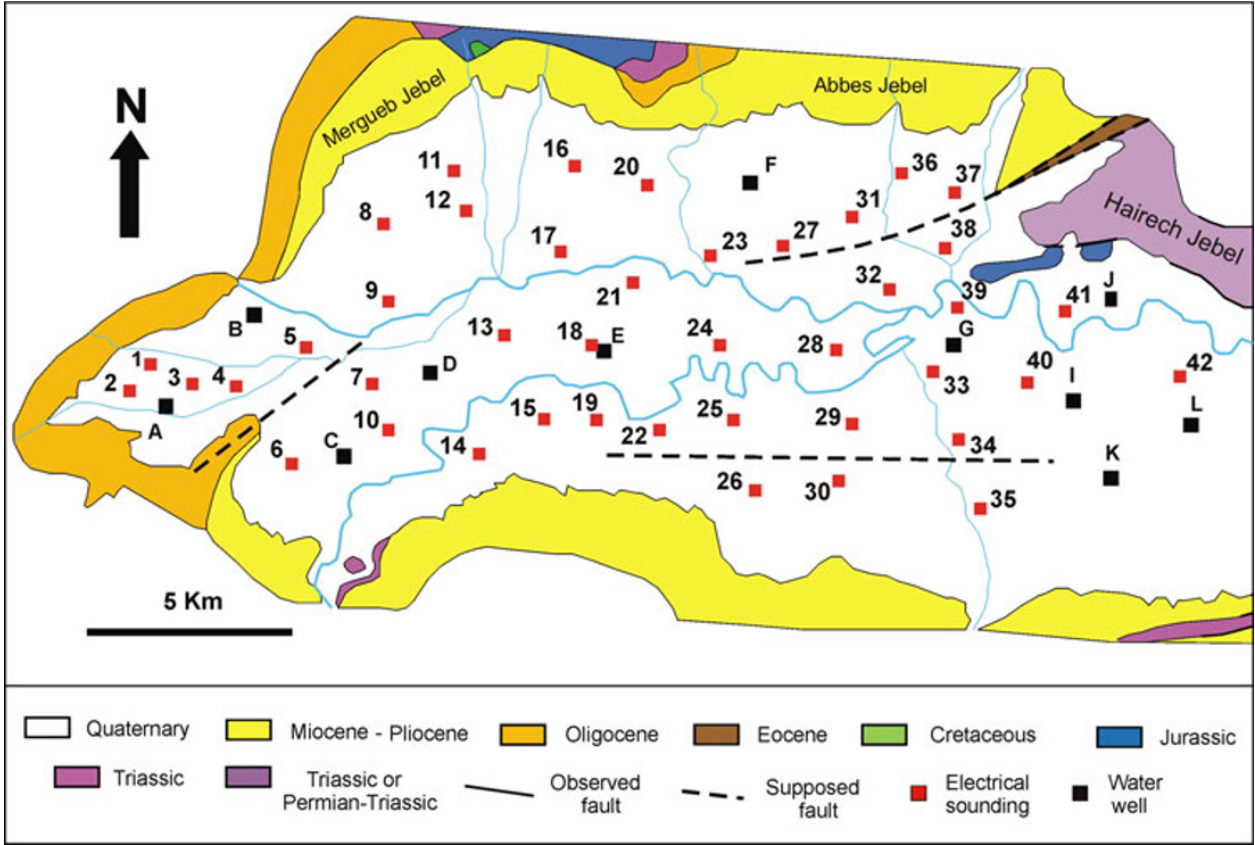

$\rho_{\mathrm{a}}=f(\mathrm{AB} / 2)$ may be interpreted as fitting different geoelectrical models. Geological data were needed to constrain the results and to solve the observed ambiguities, so that interpretation provides a realistic geological model.

The existing drilled boreholes (Fig. 4) allowed the calibration of the proximal VES. However, the available lithological columns are reconstituted from drill cuttings, which do not guarantee exact information concerning the position and the composition of the reservoirs' layers. Therefore, precise restitution of lithology requires the use of well logs (Kleh et al. 2002; Hsie et al. 2005).

Well log invented in France by Conrad Schlumberger and Henri Doll, is a continuous recording of geophysical parameters along a borehole (Desbrandes 1968). The most appropriate name of this recording is a wireline geophysical well $\log$, conveniently shortened to well $\log$ or $\log$. 
Fig. 5 Lithological columns restitution using well logs. Case of borehole $\mathrm{E}$

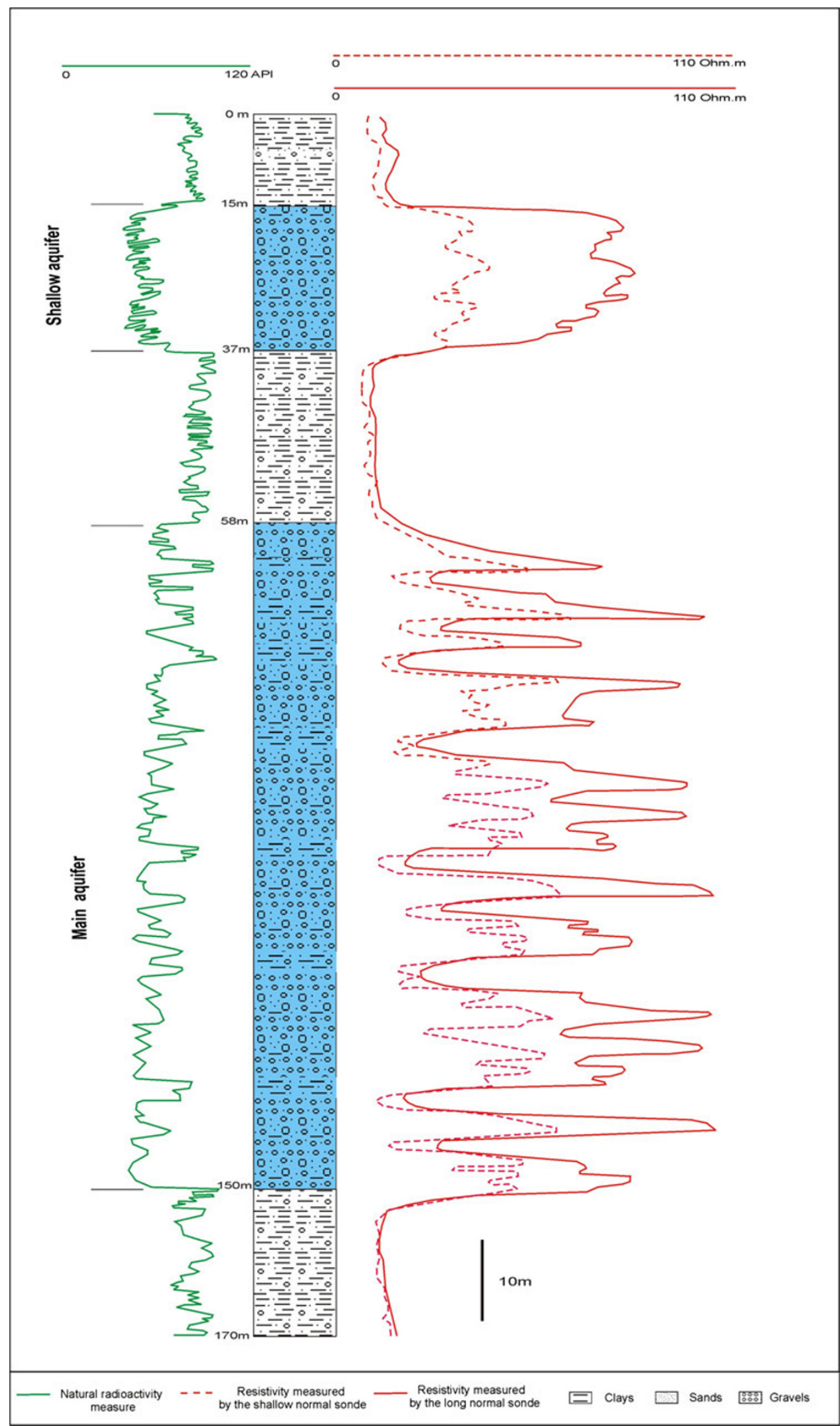


Fig. 6 Calibration of VES 18 with the borehole $\mathrm{E}$ ( $\rho$ is the layer resistivity in $\Omega \mathrm{m}$ )

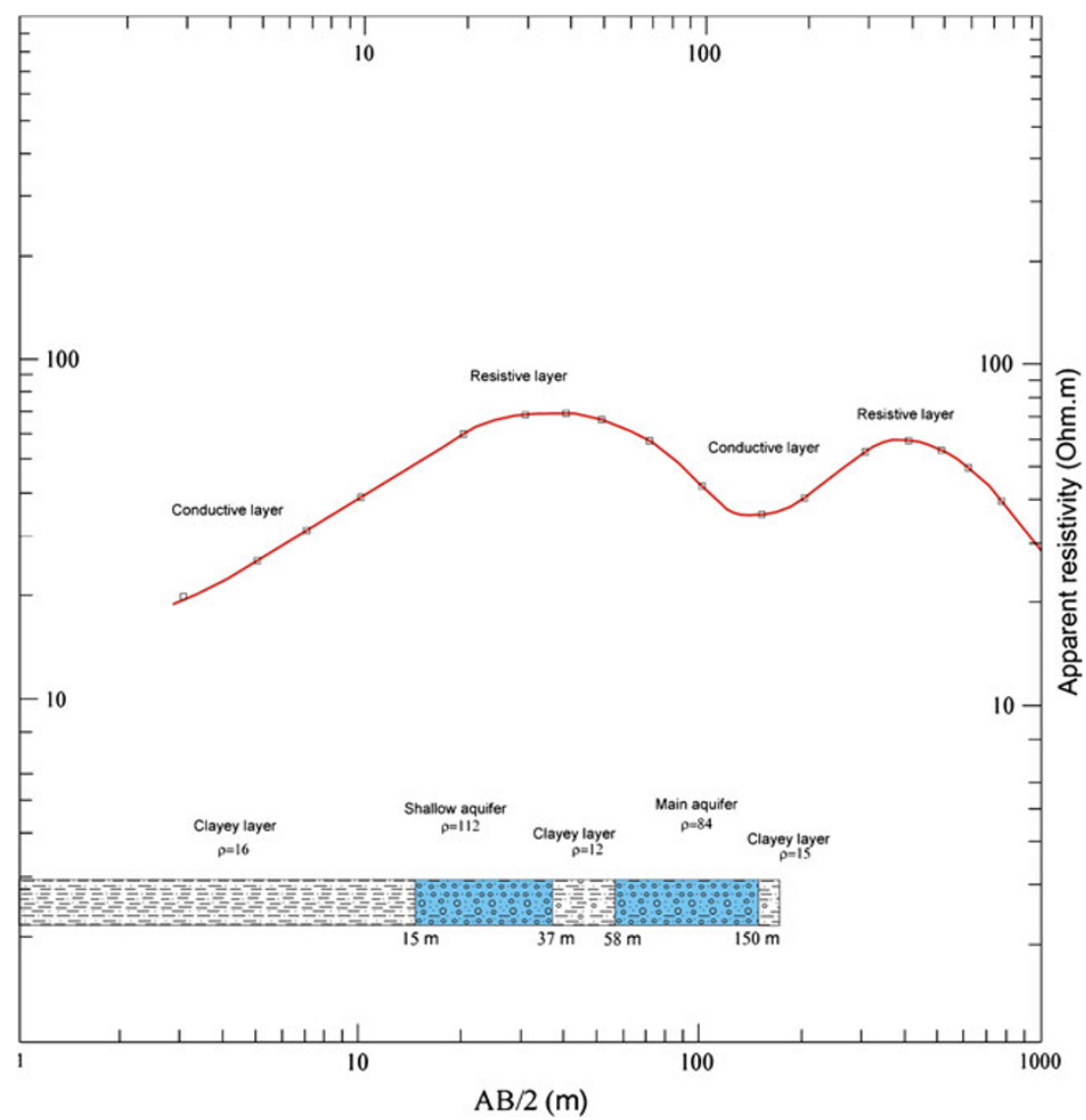

In this work, the studied physical parameters are the natural radioactivity and the resistivity, measured by short $\left(16^{\prime \prime}\right)$ and long $\left(64^{\prime \prime}\right)$ normal sondes. The Short Normal sonde also called 16-inch Normal, measures the resistivity of a sphere about $3 \mathrm{ft}$ in diameter. This shallow reading curve is influenced by the drilling fluid. The long Normal sonde which is also called 64-inch Normal, measures the resistivity of a sphere about $10 \mathrm{ft}$ in diameter, making this device suitable for deep resistivity reading (Desbrandes 1968; Serra 1984; Hearst and Nelson 1985; Rider 1986; Chapellier 1992; Ellis and Singer 2007).

Contrary to gravels and sands, clays show high natural radioactivity values: 100-200 API (American Petroleum Institute units). They are characterized by low resistivity responses (2-20 $\Omega \mathrm{m})$. The resistivity of gravels and sands can vary over several orders of magnitude depending on their pore-water salinity. Fresh waters tend to be resistive while saline brines are very conductive (Telford et al. 1976).

The comparison between the restored lithological column of borehole E (Fig. 5) and the curve of VES 18 (Fig. 6) permitted us to link resistivity and facies. The shallow and main aquifers which are constituted of coarse deposits and are characterized by a low-water salinity $(0.93 \mathrm{~g} / \mathrm{l}$ for the shallow aquifer and $1.28 \mathrm{~g} / \mathrm{l}$ for the main aquifer) show high resistivity ( $\rho$ ) values, 112 and $84 \Omega$ m, respectively .

The interpretation of the rest of VES according to the relationship between resitivity and facies obtained from borehole $\mathrm{E}$ and VES 18, provides the necessary data to elaborate the isobaths and isopachs maps of these aquifers. These maps show the tectonic structures affecting the shallow and main aquifers of Ghardimaow and their analysis can provide information about the aquifers geometry.

The geoelectrical cross sections, integrating both restored lithological columns and VES interpretation, clarify the relationship between the different hydrogeological compartments and help to improve the understanding of the aquifer functioning.

\section{Results and discussions}

Isobath and isopach maps

The isobath maps of the botton of the shallow aquifer (Fig. 7a) and the main aquifer (Fig. 7b) reflect the major deformations, which affect the Quaternary deposits in the Ghardimaou area. 


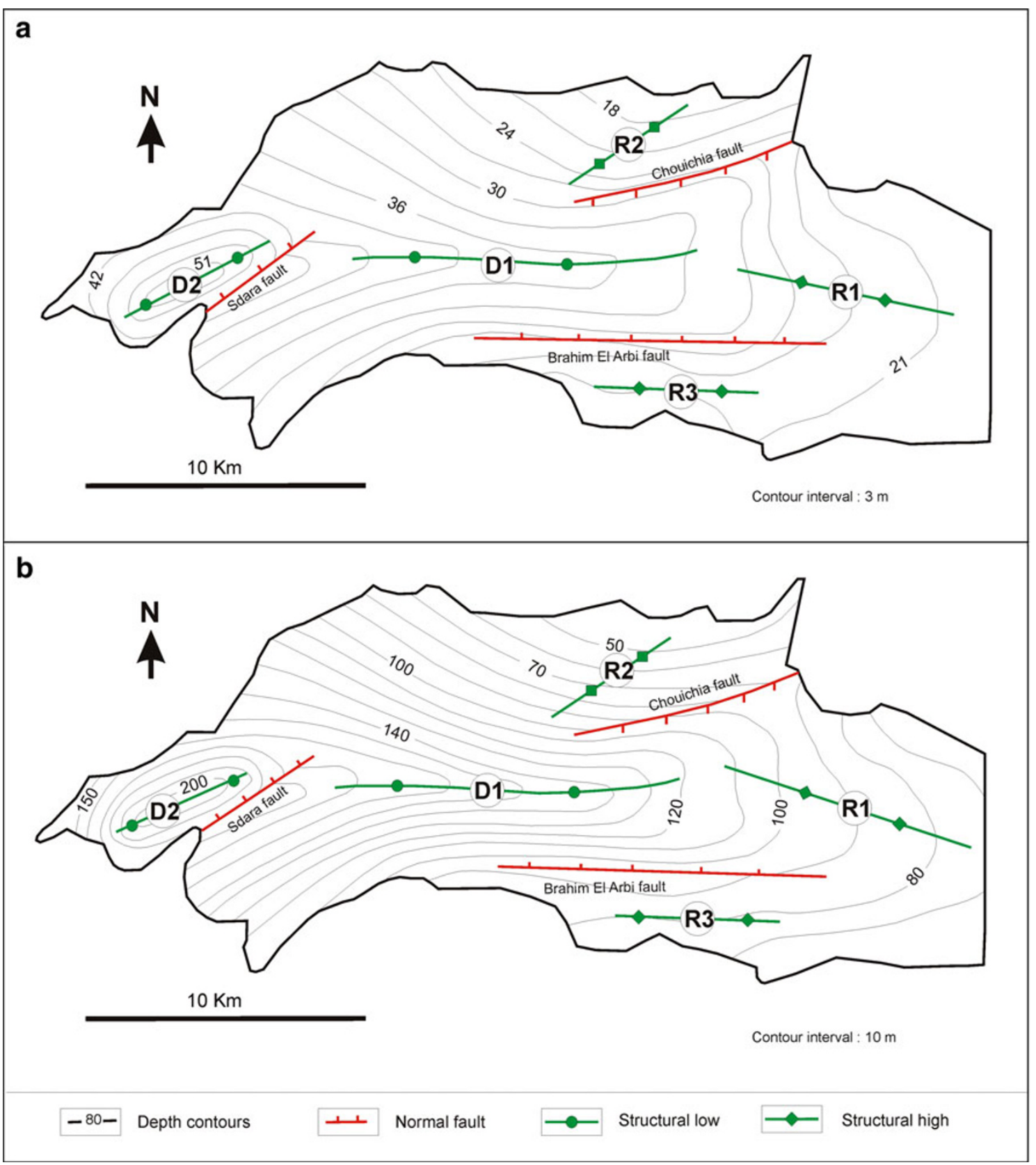

Fig. 7 Isobath maps of the shallow (a) and main (b) aquifers

These maps show a succession of east-west structures: a large basin in the Centre "D1" borded by a raised zone "R1" in the east. Similar features were described at the Mejerda molassic borders and attributed to the Villafranchian compression (Rouvier 1977; Ben Ayed 1986; Gueddiche1992; Gueddiche et al. 1992; Ould Begga 2003). This suggests that the structures characterizing the Ghardimaou aquifer system are east-west folds formed during this phase.

Towards the western extremity of the plain, the basin "D1" evolves to a deep depression "D2" where the shallow and main aquifers' bottom reach their maximum depths, respectively, 51 and $200 \mathrm{~m}$ depth. Reactivated in normal fault, the Sdara fault is responsible for the sedimentation downwarping in the structure "D2". The reactivation as-normal faulting — of Chouichia and Brahim-El Arbi faults generated, respectively, the horsts " $R 2$ " and "R3" limiting the collapsed basin "D1" in the northeast and in the south. These deformations can be related to the late Quaternary extension, highlighted at the Mejerda molassic borders (Rouvier 1977; Ben Ayed 1986; Gueddiche 1992; Gueddiche et al. 1992; Ould Begga 2003). 


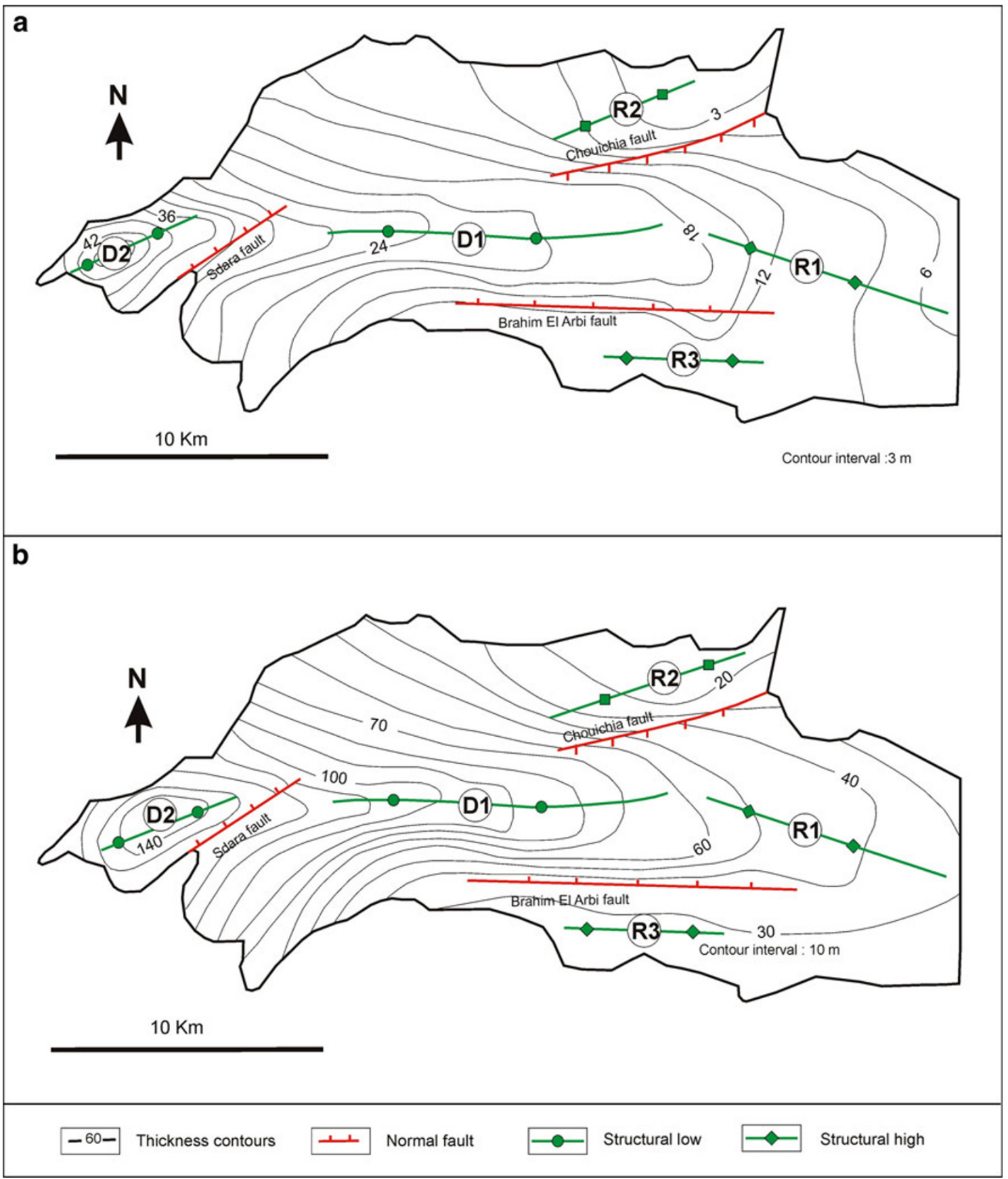

Fig. 8 Isopach maps of the shallow (a) and main (b) aquifers

Therefore, the resulting structural maps of the Ghardimaou area (Fig. 7) reveal that in addition to the tectonic features described on the geological map more important structures exist in subsurface, which must be taken into consideration to characterize the hydrogeological system.

The obtained results highlighted the tectonic influence on the shallow and main aquifer geometry; the Villafranchian folding and normal faulting during the late Quaternary extension phase compartmentalized the aquifer in the form of tilted blocks.
The isopach maps of the shallow (Fig. 8a) and main aquifers (Fig. 8b), compared to the isobath maps show the same traits. The aquifer thicknesses are higher in the depressions "D1" and "D2" than in the raised zones "R1", "R2" and "R3"; the maximum values (45 $\mathrm{m}$ thick for the shallow aquifer and $140 \mathrm{~m}$ thick for the main aquifer) characterize the basin "D2", the deepest structure in the Ghardimaou plain.

Therefore, the tectonic deformations affecting the Quaternary series control the aquifer depth and thickness. 


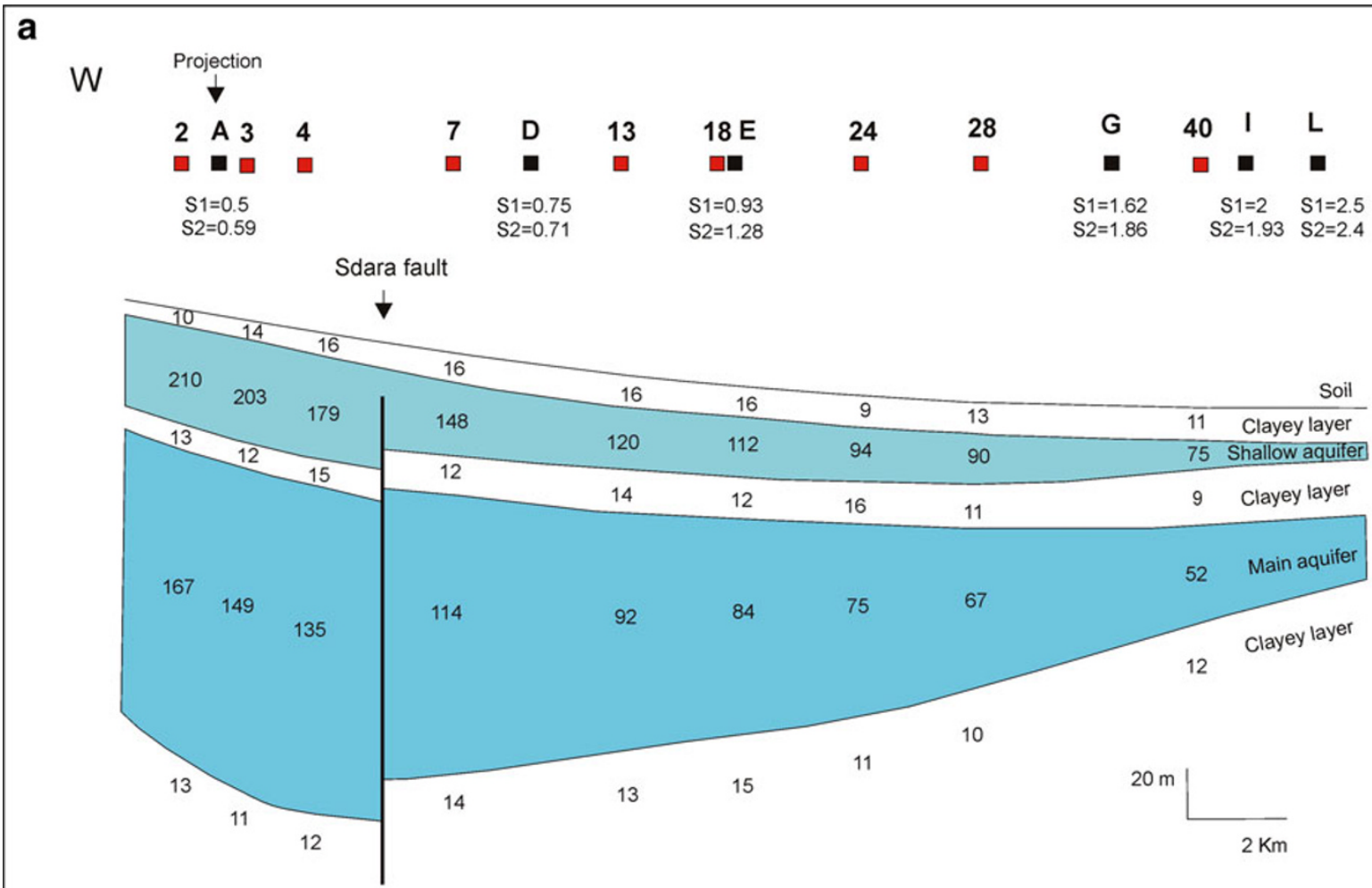

b

S 35 34

$\begin{array}{lll}33 & \text { G } & 39\end{array}$

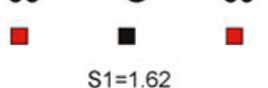

$\mathrm{S} 1=1.62$

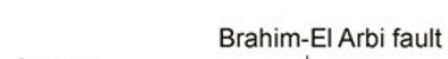

E Soil 
Fig. 10 Gamma ray logs comparison between the western, central and eastern parts of the Ghardimaou plain

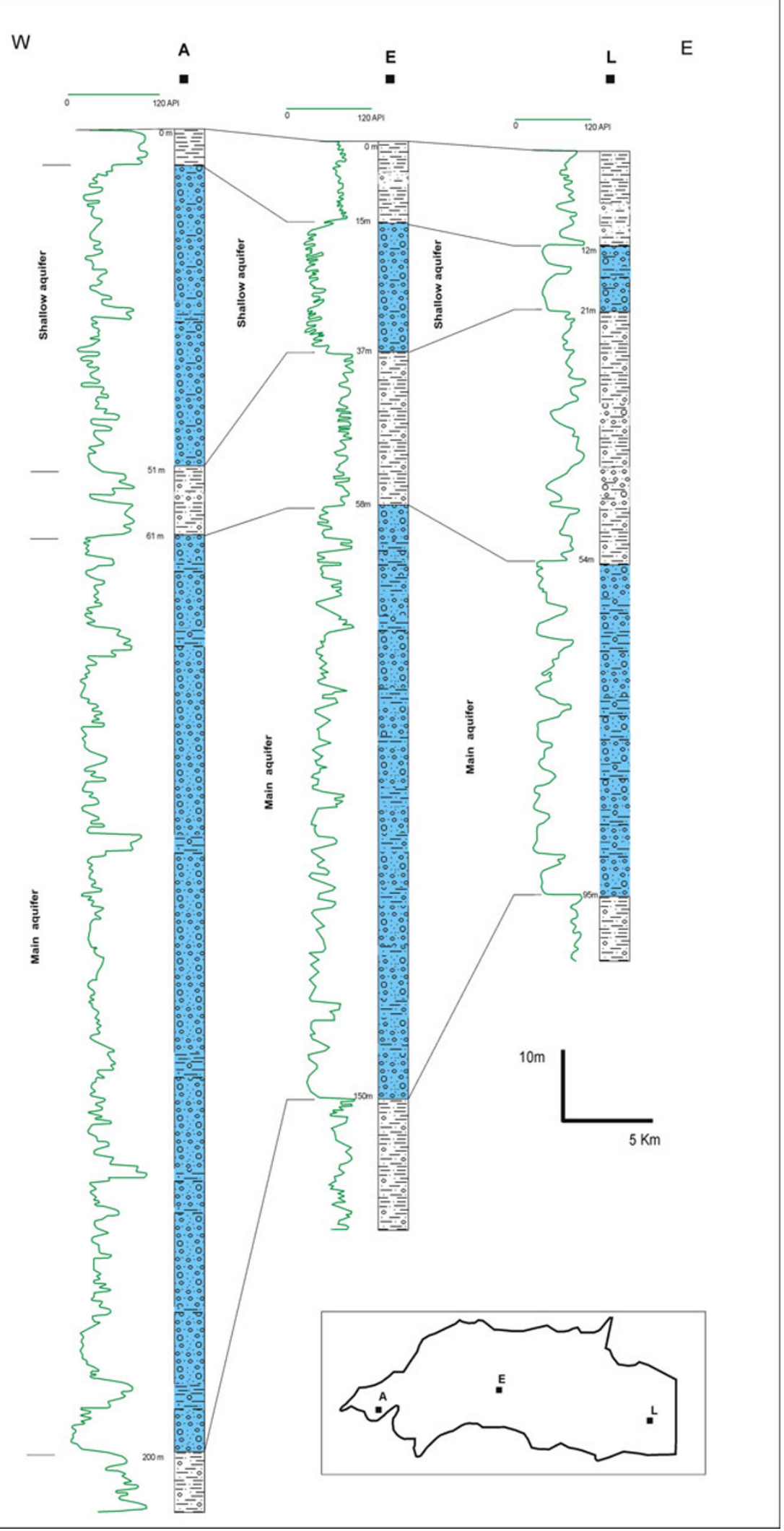




\section{Geoelectrical cross sections}

The geoelectrical cross sections represented in Fig. 9a and b oriented, respectively, E-W and $\mathrm{N}-\mathrm{S}$ show the influence of the derived reservoirs geometry on the connection between the different aquifer blocks.

The geoelectrical cross section (a) shows gradual decrease in the resistivity values toward the east in both the shallow and main aquifers. Sedimentary and chemical phenomena explain this evolution. The water salinity of shallow and main aquifers increases from the west (Well A: 0.5 and $0.59 \mathrm{~g} / 1$, respectively, for the shallow and the main aquifers) to the east (Well L: 2.5 and $2.4 \mathrm{~g} / 1$, respectively, for the shallow and the main aquifers) which agrees with the groundwater flow direction. It is interesting to note that the shallow and main aquifers have similar water salinity values suggesting a common recharge source and may be a vertical exchange between the aquifers.

In addition, the shallow and main aquifers are progressively enriched in clayey sediments toward the east. The comparison of the Gamma Ray logs corresponding to both aquifers (Fig. 10) reflects this lateral lithological change. In well A, only a few intervals show high radioactivity values. These intervals are more developed in well E, whereas in well $\mathrm{L}$ they are thicker and more frequent.

This evolution is especially clear in the main aquifer. Besides, the well log comparison shows a notable thickening of the clayey aquicludes which separate the two aquifer formations.

The reduction of coarse sediments in favor of clayey sediments toward the east is also observed on the surface. This evolution is perfectly coherent with the mechanisms of sedimentation in the plains of flood flow (Claude et al. 1973; Naoui 1995; Ballais et al. 1998; Degoutte 2006). Therefore, at each Oued Mejerda flood a granulometric sorting is carried out where the coarse elements are initially deposed.

The geoelectrical cross section in Fig. 9a reveals that the Sdara fault affects both the shallow and main aquifers without influencing the communication between the reservoirs in the depressions "D1" and "D2".

The northern part of the geoelectrical cross section in Fig. 9b shows a blocked exchange between the reservoir formations. The Chouichia normal fault has isolated the aquifers in the horst "R2" which are in direct contact with clayey layers deposed in the depression "D1".

The difference between the resistivity of the aquifers at neighboring points VES 38 (64 $\Omega \mathrm{m}$ for the shallow aquifer and $58 \Omega \mathrm{m}$ for the main aquifer) and VES 37 (48 $\Omega \mathrm{m}$ for the shallow aquifer and $39 \Omega \mathrm{m}$ for the main aquifer) may be related to the limited or nonexistent connection between the folded structures "R2" and "D1".
The relatively low aquifer resistivity at VES 37 is related to the high water salinity $(3 \mathrm{~g} / \mathrm{l})$ of Oued Melah river, the main recharge source of the permeable formations in the horst "R2".

In the southern part of the geoelectrical cross section (b), the reservoirs situated in the raised zone "R3" are in contact with their equivalents deposed in the depression "D1". Therefore, the Brahim-el Arbi fault only controls the aquifer depth and thickness.

\section{Conclusion}

This study is based on Vertical Electrical Soundings as well as on wells data and displays the tectonic deformations which affect the multilayered Quaternary aquifer in the Ghardimaou area.

The Villafranchian folding and the normal faulting during the late Quaternary extension phase compartmentalized the aquifer in raised and subsided blocks. The isobath and isopach maps, and the geoelectrical cross sections show that this structure has variable implications, for instance influencing the permeable formations' depth and thickness all over the area. The structure is also responsible for a limited or nonexistent hydrogeological connection between the compartments "R2" and "D1" in the northeastern part of the plain where the Chouichia fault obstructs the reservoir communication.

These results will be useful for choosing the best sites for the exploitation of the Quaternary aquifers in the Ghardimaou area.

In addition, the present study shows the applicability of the electrical resistivity method for the understanding of hydrogeological systems when the well data are limited for a precise characterization. Such prospection was suitable in this study in view of the importance of the tectonic structures which are not easily detectable by simple well correlations.

Open Access This article is distributed under the terms of the Creative Commons Attribution License which permits any use, distribution and reproduction in any medium, provided the original author(s) and source are credited.

\section{References}

Alouani R, Tlig S (1988) Allochtonous metamorphic units of the axis of Jebels Hairech and Ichkeul: structural position and geodynamic significance in northern Tunisia. C R Geosci 306: 1373-1378

Alouani R, Adil S, Mouguina M (1991) Allochtonous metamorphic units of the axis of Jebels Hairech and Ichkeul: structural position and geodynamic significance in northern Tunisia. C R Geosci 313:421-426 
Andrieux M, Talbot A (1972) Etude hydrogéologique et prospection électrique de la haute vallée de la Mejerda Tunisie (Hydrogeological study and electrical prospecting in the high Mejerda valley. Tunisia). DGRE Report, Tunisia

Asfahani J (2006) Geoelectrical investigation for characterizing the hydrogeological conditions in semi-arid region in Khanasser valley, Syria. Arid Environ J 68:31-52

Ballais JL, Marre A, Mietton M, Miossec A, Morin S, Valadas B, Veyret Y (1998) L'érosion entre nature et société (Erosion between nature and society). SEDES, France

Ben Ayed N (1986) Evolution tectonique de l'avant pays de la chaîne alpine de la Tunisie du début du mésozoïque à l'actuel (Tectonic evolution from the Mesozoic to the Recent). Es-Sciences Thesis, University Paris Sud, p 327

Biely A (1972) Le Néogène en Tunisie septentrionale (Neogene in Northern Tunisia). Geological Report, Tunisia

Bolze J (1954) Age des séries schisteuses et dolomitiques de l'Ichkeul et de l'Hairch, Tunisie septentrionale (Age of schist and dolomite series of Ichkeul and Hairch, Northern Tunisia). C R Geosci 20:2008-2010

Burollet PF (1973) Importance des fractures salifères dans la tectonique tunisienne (Importance of salt fractures in Tunisian tectonics). Mines Geol Ann Tunisia 26:111-120

Chapellier D (1992) Well logging in hydrogeology. Balkema, USA

Claude J, Francillon G, Loyer J (1973) Les alluvions déposées par oued Mejerda lors des crues exceptionnelles de Mars 1973 (Alluvia deposed by Mejerda Oued during exceptional flood of March 1973). ORSTOM, Tunisia

Cudennec C, Leduc C, Koutsoyiannis D (2007) Dryland hydrology in Mediterranean regions review. Hydrogeol Sci J 52:1077-1087

Degoutte G (2006) Diagnostic, aménagement et gestion des rivières: hydraulique et morphologie fluviales appliquées (Diagnosis, planning and management of rivers: applied fluvial hydraulic and morphology). Lavoisier, France

Desbrandes R (1968) Théorie et interprétation des diagraphies (Theory and interpretation of well logs) Technip Edn, France, p 578

Dlala M (1995) Evolution géodynamique et tectonique superposée en Tunisie: implication sur la tectonique récente et la sismicité (Geodynamic evolution and associated tectonics in Tunisia: implication on recent tectonics and seismicity). Es-Sciences Thesis, Tunis II University, Tunisia

Dobrin MB (1976) Introduction to geophysical prospecting. Mc Graw-Hill, New York

Ellis DV, Singer JM (2007) Well logging for earth scientists. Springer, Berlin

Gottis CH, Sainfeld P (1955) Notice de la carte géologique de Ghardimaou (Sheet memoir of Ghardimaou geological map). Geol Serv, Tunisia

Gouasmia M, Gasmi M, Mhamdi A, Bouri S, Ben Dhia H (2006) Prospection géoéléctrique pour l'étude de l'aquifère thermal des calcaires récifaux Hmeima-Boujaber, Centre ouest de la Tunisie (Geoelectrical prospecting for studying the thermal aquifer of reef limestone, Hmeïma-Boujabeur, central-western Tunisia). C R Geosci 338:1219-1227

Gueddiche M (1992) Analyse de la sismicité en Tunisie et étude sismique, sismotectonique et néotectonique de la Tunisie septentrionale (Seismicity analyze in Tunisia and seismic, seismotectonic and neotectonic study of northern Tunisia). PHD thesis, Paris VI University, France

Gueddiche M, Harjono H, Ben Ayed N, Hfaied M, Diament M, Dubois J (1992) Analyse de la sismicité et mise en évidence d'accidents actifs dans le Nord de la Tunisie (Seismicity analyze and highlighting of active accidents in northern Tunisia). Bull Soc Geol 4:415-425

Guellala R (2004) Identification des aquifères potentiels de la Haute Vallée de la Mejerda. Apport des données électriques et diagraphiques dans l'étude du Plio-Quaternaire continental (Identification of potential aquifers in Mejerda high valley. Electrical and well $\operatorname{logs}$ data contribution to the continental Pliocene-Quaternary deposits study). Master memory, Tunis II University, Tunisia

Guellala R, Inoubli MH, Alouani R, Manaa M, Amri F (2005a) Caractérisation des réservoirs aquifères de la Haute Vallée de la Mejerda, Tunisie (Characterization of the Mejerda high valley aquifers (Tunisia). Afri Geosci Rev 12:189-202

Guellala R, Inoubli MH, Alouani R, Manaa M, Amri F (2005b) Contribution à l'étude hydrogéologique de la plaine de Ghardimaou-Oued Meliz,Tunisie (Contribution to the hydrogeological study to the Ghardimaou-Oued Meliz plain, Tunisia). WATMED 2, Morocco

Guellala R, Inoubli MH, Amri F (2008) Nouvelles données géologiques sur la plaine de la Haute vallée de la Mejerda, Tunisie (New geological data on the plain of the high valley of Mejerda, Tunisia). Serv Geol Notes Tunisia 76:103-113

Guellala R, Inoubli MH, Amri F (2009a) Nouveaux éléments sur la structure de l'aquifère superficiel de Ghardimaou, Tunisie: contribution de la géophysique électrique (New elements on the structure of Ghardimaou shallow aquifer, Tunisia: electrical geophysics contribution). Hydrogeol Sci J 54:974-983

Guellala R, Inoubli MH, Amri F (2009b) Apport de la méthode électrique à l'étude hydrogéologique de la plaine de Bousalem, Nord-Ouest de la Tunisie (Geoelectrical prospecting for groundwater exploration in Bou Salem area, northwestern Tunisia). CMGA 4, Tunisia, p 219

Guellala R, Ben Marzoug H, Inoubli MH, Moumni L (2011a) Apports de la Sismique Réflexion à l'étude de l'aquifère du Continental Intercalaire du Jérid, Tunisie (Seismic reflection contribution to the study of the Jerid Continental Intercalaire aquifer, Tunisia). Hydrogeol Sci J 5:1040-1052

Guellala R, Inoubli MH, Moumni L, Zouaghi T (2011b) Seismic reflection contribution to the study of the Jerid Complexe Terminal aquifer (Tunisia). In: Geophysics book, Intech publisher, Austria. ISBN: 979-953-307-368-1

Guellala R, Inoubli MH, Amri F (2011c) New elements on the hairech metamorphic massif structure (Northwest Tunisia). Geoelectrical prospecting contribution. Geog Geol J 3:160-170

Guellala R, Inoubli MH, Amri F (2010) Hydrogeological study of Oued Bouhertma zone. Geoelectrical prospecting contribution. In: Tunisia-Japan Symposium. Regional Developement and water Resource, Tunisia, pp 227-229

Hearst JR, Nelson PH (1985) Well logging for physical properties. Mc Graw-Hill, New York

Hfaiedh M, Chadi M, Allouche M (1985) Seismicity of Tunisia and neighbouring areas. In: Proceedings of the second workshop on the european geotraverse (EGT) project, pp 261-267

Hsie BZ, Lewis C, Lin ZS (2005) Lithology identification of aquifers from geophysical well logs and fuzzy logic analysis: Shui-Lin Area, Taiwan. Comput Geosci J 31:263-275

Jenny J, Borreguerro M (1993) WINSEV: SEV interpretation program. W-Geosoft, Geneva

Keller GV, Frischknecht FC (1982) Electrical methods in geophysical prospecting. Pergamon, Oxford

Kleh M, Eichorst F, Schafer A (2002) Facies interpretation from wells logs applied to the tertiary lower Rhine basin fill. Geosci Neth J 2:167-176

Koussoubé Y, Nakolendoussé S, Bazié P, Savadogo AN (2003) Typologie des courbes de sondages électriques verticaux pour la reconnaissance des formations superficielles et leur incidence en hydrogéologie de socle cristallin du Burkina Faso (Different types of vertical electrical soundings for upper soils recognition and their part in hydrogeology of crystalline basement of Burkina Faso). Sud Sci Technol J 10:26-32 
Krima A (2001) Etudes néotectoniques et sismotectoniques de la région de Ghardimaou (Nord-Ouest de la Tunisie) (Neotectonic and seismotectonic studies of Ghardimaou area (northwestern Tunisia). DEA memory, Tunis II University, Tunisia

Majumdar RK, Majumdar N, Mukhjee AL (2000) Geoelectric investigation in Bakreswar geothermal area, West Bengal, India. Appl Geophys J 45:187-202

Meyer de Stadelhofen C (1991) Applications de la géophysique aux recherches d'eau (Geophysics applications in water researches). Lavoisier, Paris

Naoui L (1995) Le lit fluvial et la vallée alluviale de la Mejerda: Etude de dynamique et de géomorphologie fluviales (River bed and alluvial valley of Mejerda (fluvial dynamics and geomorphology). PHD thesis, Nanterre University, France

Ould Begga M (2003) Evolution tectono-sédimentaire et analyse structurale d'un segment des maghrebides orientales: la region de Ghardimaou-Fernana, Tunisie nord-occidentale. (Tectonicsedimentary evolution and structural analysis of the Maghrebides eastern segment: Ghardimaou-Fernana region, northwestern Tunisia). PHD Thesis, Tunis II University, Tunisia

Ould Begga M, Abdeljaoued S, Mercier E (2006) La zone des nappes de Tunisie, une marge méso-cénozoique en blocs basculés modérément inversé, région Taberka-Jendouba, Tunisie nordoccidentale) (Thrust nappes of Tunisia, Mesozoic-Cenozoic margin in tilted blocks, moderately reversed, Taberka-Jendouba region, northwestern Tunisia). Bull Soc Geol 3:145-154

Parsons Company (1967) Rapport final sur les recherches des eaux souterraines, vallée de la haute Mejerda (Final report on groundwater researches, high Mejerda valley). DGRE report, Tunisia

Perthuisot V (1978) Dynamique et pétrogenèse des extrusions triasiques en Tunisie Septentrionale (Dynamics and petrogenesis of Triassic extrusions in northern Tunisia). Es-Sciences Thesis, Pierre et Marie Curie University, France

Pertu N, Wattanasen K, Phommasone K, Elming SA (2011) Characterization of aquifers in Vientiane Basin, Laos, using magnetic resonance sounding and vertical electrical sounding. Appl Geoph J 73:207-220

Rapti-Caputo D, Bratus A, Santarato G (2009) Strategic groundwater resources in the Tagliamento River basin (northern Italy): hydrogeological investigation integrated with geophysical exploration. Hydrogeol J 17:1393-1409

Riahi S, Soussi M, Boukhalfa K, Ben Ismail-Lattrache K, Dorrik S, Khomsi S, Bedir M (2010) Stratigraphy, sedimentology and structure of the Numidian Flysch thrust belt in northern Tunisia. Afri Earth Sci J 57:109-126

Rider MH (1986) The geological interpretation of wells logs. Blackie, Chicago

Rouvier, H. (1977) Géologie de l'extrême nord tunisien: tectonique et paléogéographie superposées à l'extrême orientale la chaîne nord maghrébine (Geology of northern Tunisia: tectonics and paleogeography associated to the eastern extreme of maghrebine chain). Es-Sciences thesis, Thèse es Sci., Univ. Paris VI, France

Serra O (1984) Fundamentals of well log interpretation. The acquisition of logging data. Elsevier, Amsterdam

Shaaban F (2001) Vertical electrical soundings for groundwater investigation in northwestern Egypt: a case study in a coastal area. Afri Earth Sci J 33:673-686

Telford WM, Geldart BP, Sheriff RE (1976) Applied Geophysics. Cambridge University Press, London

Tizro AT, Voudouris KS, Salehzade M, Mashayekhi H (2010) Hydrogeological framework and estimation of aquifer hydraulic parameters using geoelectrical data: a case study from West Iran. Hydrogeol J 32:917-929

Zouhri L (2001) L'aquifère du basin de la Mamora, Maroc: géométrie et écoulement souterrains (Aquifer of the Mamora basin, Morocco: geometry and groundwater flow). Afri Earth Sci J $32: 837-850$

Zouhri L, Gorini C, Mania J, Deffontaines B, Zerouali A (2004) Spatial distribution of resistivity in the hydrogeological systems, and identification of the catchment area in the Rharb basin, Morocco. Hydrogeol Sci J 49:387-398 